\title{
Adaptation of Academic Entitlement Questionnaire
}

\author{
Y1ldı KURTYILMAZ ${ }^{1}$
}

Submitted by 18.10 .2018

Accepted by 10.06.2019

Research Paper

\begin{abstract}
Academic entitlement is one of the most significant problems that affect not only students' academic success but also lead them to engage in various uncivil and undesired behaviors such as disrespect, anger and aggression. It might disrupt individuals' psychological and social adaptation by itself or interacting with other problems. Academically entitled students are inconsiderate of their friends, intolerant to even constructive feedback, and exhibit unethical behaviors such as cheating, plagiarism, etc.. This global phenomenon is a significant problem in Turkey as well. Therefore, the need for having a sound grasp of academic entitlement led to initial reliability and validity studies of Academic Entitlement Questionnaire in Turkish Culture in this study. Analyses were carried out on 469 participants data, 351 (75\%) of whom were females and $118(25 \%)$ of whom were males. It was found that Turkish and English forms were equivalent, the construct with a-five-item unidimensional scale was confirmed. Furthermore, for concurrent validity, relationship between academic entitlement and similar structures of narcissism, entitlement and academic self-efficacy was investigated. Results indicated that academic entitlement was found to be significantly related to narcissism and entitlement and negatively related to academic selfefficacy. This indicates that academic entitlement despite related to these three structures is a different construct. For reliability, internal consistency coefficients and test-retest methods were used. These analyses indicated that the scale assess academic entitlement consistently. Thus, it can be stated that Academic Entitlement Questionnaire is a valid and reliable instrument for measuring academic entitlement of Turkish university students.
\end{abstract}

Keywords: Academic entitlement, narcissism, entitlement

\footnotetext{
1 Anadolu Üniversitesi, Eğitim Fakültesi, Eğitim Bilimleri Bölümü, e-mail: ykurtyilmaz@anadolu.edu.tr
} ORCID: 0000-0003-0298-4579 
AJESI - Anadolu Journal of Educational Sciences International, 2019; 9(2): 314-351

DOI: 10.18039/ajesi.577234

\section{Introduction}

Nowadays, not only positive changes but also many problems are experienced in educational contexts. Some of these problems are directly related to academic issues such as academic disinterest, indifference or failure whereas some are related to behavioral problems such as disrespect, anger and aggression (Juvonen, Le, Kaganoff, Augustine, \& Constant, 2004). On the other hand, some problems not only negatively affect the academic success of an individual but also lead individuals to exhibit behavioral and adjustment problems in academic context through shaping his/her attitudes and behaviors toward academic life (Kazdin, 1993; Kershaw, 1992; Roeser, Eccles, \& Sameroff, 1998). Academic entitlement is one of the most significant problems that affect students' academic success and lead them to engage in undesired behaviors such as disrespect, anger and aggression through attitudes towards learning and academic environment (Chowning \& Campbell, 2009).

The concept of academic entitlement has been defined differently in the literature, but in this study the following definition of academic entitlement is adopted. Academic entitlement is defined as preferring to receive more from one's academic experience than one's peers and preferring to get more from one's academic experience than one gives to it (Miller, 2013, p. 656). It is displayed as unreasonable expectations from professors like availability and responsiveness of professors whenever students wish (Singleton-Jackson, Jackson, \& Reinhardt, 2010); an expectation of high grades despite not fulfilling the criteria, or standards, of achievement (Singleton-Jackson, Jackson, \& Reinhardt, 2011); and an expectation of some privileges and exceptions for them (Achacoso, 2002). In addition, academically entitled students are more interested in what others- professors, university, etc.,should do or not do for them instead of focusing on their own responsibilities (work hard, learn as much as possible) as a student (Chowning \& Campbell, 2009; Singleton-Jackson, Jackson, \& Reinhardt, 2011). 
AJESI - Anadolu Journal of Educational Sciences International, 2019; 9(2): 314-351

DOI: 10.18039/ajesi.577234

Academically entitled students think that they should be given higher grades based on just their effort although they do not meet the achievement criteria, or they're unsuccessful (Singleton-Jackson, Jackson, \& Reinhardt, 2011). For example, they think that they deserve getting high grades just because they attend to classes or complete their homework (Chowning \& Campbell, 2009). At the same time, the students with high academic entitlement assume that they should be exempt from the rules others follow and receive special treatment. Those students have expectations such that they are given the chance of taking a makeup exam regardless of the reason for not taking the exam, they are provided with the opportunity of being late for class and leaving class early and their homework submission date is postponed just because they can't submit their homework on time (Greenberger, Lessard, Chen \& Farruggia, 2008). Moreover, academically entitled students do not take their own responsibilities as a student. Their responsibilities are just to attend their courses, to study their lessons and to learn the subject matter of the course, and to pass the exams and to get the grades by meeting the requirements of the course, but they expect their professors and university should ensure, or pave the way for, success and the graduation irrespective of their real performance (Lombardi, 2007; Reinhardt, 2012). That is, the individuals exhibiting academically entitled behaviors feel entitled to academic achievement, and they find the desire to get higher grade without making much more effort is normal. On the other hand, Achacoso (2002) stated that expecting higher grades is much more than the intense desire or hope, and it is perceived by academically entitled students as something that should be.

Students get used to have higher grades for less effort due to changing education systems. When they start university, such habits and behavioral patterns affect their academic efforts (Twenge \& Campbell, 2008). In other words, when students start university, they are not prepared enough for the requirements and obligations of academic life at university 
AJESI - Anadolu Journal of Educational Sciences International, 2019; 9(2): 314-351 DOI: 10.18039/ajesi.577234

(Miller \& Murray, 2005; Pimentel, 2011) and they plan to pass courses or get higher grades by making less effort continuously (Luckett, Trocchia, Noel \& Marlin, 2017). Therefore, academic entitlement is more frequently observed especially in university students (Luckett et al., 2017; Twenge, 2009). Since students do not accept the results proportional to their efforts and always expect more, they cannot acquire the information and skills they must acquire in educational process resulting in that academic entitlement causes a decrease in education quality (Luckett et al., 2017). In the literature it has been indicated that academic entitlement leads to some problems such as academic dishonesty, lower self esteem (Greenberger et al. 2008), tolerance to academic dishonesty (Shapiro, 2012), low levels of responsibility, frustration intolerance and a decrease in academic achievement (Anderson, Halberstadt, \& Aitken), thus a decrease in the quality of academic institutions (Hwang, 1995; Morrow, 1994), and so on.

The priority of academically entitled students is not a learning any more (Hartman, 2012). Most of the students view education as a means of getting a better job, status, and more money (Lippmann et al., 2009). The students with high academic entitlement are not concerned with learning the subjects and improving themselves in the field (Reinhardt, 2012). Hence, the quality of graduates decreases and the university degrees become meaningless because degrees and diplomas are granted and even distributed to the students with poor performance irrespective of performance and success. (Morrow, 1994). As a result, the required vocational competencies cannot be gained by individuals, vocations cannot be performed in the way required, the productivity falls and the quality of the services provided decreases (Hartman, 2012). Therefore, academic entitlement negatively affects not only the education process but also social life indirectly (Luckett et al., 2017).

Although academic entitlement negatively affects education system, students and society in general, it is not evaluated as a problem because of the recent changes in cultural 
AJESI - Anadolu Journal of Educational Sciences International, 2019; 9(2): 314-351 DOI: 10.18039/ajesi.577234

and social life, and academically entitled individuals are perceived as demanding (Luckett et al., 2017). Consequently, academic entitlement as an implication of the contemporary educational policies and applications that emphasize only cognitive achievement and obtaining grades rather than real learning (Morrow, 1994) has been stated as a problem by faculties (Hartman, 2012), but it has been perceived neutral or positive by students (Pimentel, 2011). Because students perceiving themselves like consumer explain educational achievement as effort-based instead of product-based and this effort-based attitude toward education results in misperception of their own roles and responsibilities as a student, matching educational life only with grades, and increase their tendencies to academic entitlement (Pimentel, 2011; Singleton-Jackson, Jackson;\& Reinhardt, 2010) and certain emotional, behavioral problems. Although academic entitlement is perceived as a superficial, simple and ordinary complaints of faculties, it might disrupt individuals' psychological and social adaptation by itself or interacting with other problems. Academically entitled students display some negative behaviors that sabotage both themselves and education process (Lippmann et al., 2009) and experience various emotional problems. For example, the students, from whom academic success and relatedly higher grades are expected, become academically entitled and then anxious (Greenberger et al., 2008).

Since academically entitled students perceive academic achievement as essential rights of themselves regardless of low level of effort, they tend to feel anger and become indignant when they cannot get the outcome they expect (Achacoso, 2002; Chowning \& Campbell, 2009). They are inconsiderate of their friends, intolerant to even constructive feedback, and exhibit unethical behaviors such as cheating, plagiarism (Morrow, 1994), expecting privileges, etc. (Achacoso, 2002), because they have performance (effort)-oriented goals and try to preserve their self-perceptions by means of their higher grades anyway at all. Thus, they compete with other students and behave in a selfish way. Consequently, the students high in 
AJESI - Anadolu Journal of Educational Sciences International, 2019; 9(2): 314-351

DOI: 10.18039/ajesi.577234

academic entitlement compare themselves with other students incessantly, and they think that they are under-rewarded regardless of their actual performance (Hartman, 2012). They attribute the causes of their success or especially failure to external factors such as their teachers; they claim that the professors should make efforts for their success and they think that they are treated unjustly because they aren't given the grades they want (Miller, 2013). Moreover, they feel that their self-perceptions, which they shape with their grades, are under threat; they perceive themselves insufficient on the sly and become unhappy. At the same time, they often experience negative feelings such as disappointment, anger and fury (Kopp \& Finney, 2013). Barton and Hirsch (2016) indicated that academically entitled students had higher stress levels and poor mental health. Furthermore, depression levels of students were found to increase as they become more academically entitled. A negative relationship was also found between psychological well-being and academic entitlement. Specifically, some indicators of psychological well-being, e.g. autonomy and self-acceptance were found to be negatively related with academic entitlement. As individuals become more academically entitled, they are less autonomous and their self-acceptance levels decrease (Barton \& Hirsch, 2016). The less autonomous the individuals are, the less responsible they are. In other words, since they don't make any decision on their own, they don't take any responsibility. They attribute the causes and the consequences of their behaviors to the factors outside themselves. This explains the externalized responsibility of academically entitled students. Academically entitled students expect the faculty or the university make things easier for themselves (Achacoso, 2002). This expectation may also be linked with their external locus of control.

Individuals with external locus of control think that they can't change the outcome and their behaviors will not result in the outcome they wish. This is supported with the finding of the study that academic entitlement was found to be related with external locus of control (Kopp, Zinn, Finnely \& Jurich, 2011; Kopp \& Finney, 2013). Academically entitled students 
AJESI - Anadolu Journal of Educational Sciences International, 2019; 9(2): 314-351

DOI: 10.18039/ajesi.577234

don't believe they can get the grades by their own efforts (Chowning \& Campbell, 2009). Therefore, they don't make an effort to learn and study the subject matter of the course. As expected, they can't have a pleasure of learning for the sake of learning (Reinhardt, 2012). Thus, instead of intrinsic rewards, extrinsic rewards like high grades explained the variance in academic entitlement (Reinhardt, 2012). Similarly, academic self-efficacy (Achacoso, 2002) and course self-efficacy was found to be negatively related with academic entitlement. As students' self-efficacy decreases, their academic entitlement levels increase (Boswell, 2012). Perceiving themselves as incapable of achieving designated goals threatens students' inflated views of self-worth. To boost their fragile self-esteem, academically entitled students display more exploitative behaviors in interpersonal relationships. Exploitativeness as a maladaptive component of entitlement was found to be related with inappropriate behaviors in academics, as well (Luckett et al., 2017).

Academically entitled students were also found to be more likely to exhibit uncivil and disturbing behaviors. Uncivil student behaviors are displayed against the traditional rules and norms regulating academic atmosphere, such as being late to class, not respecting professors and classmates, and inappropriate use of smart phones during class (Chowning \& Campbell, 2009; Lippmann et al., 2009). In extreme forms, academically entitled students behave aggressively and may threaten professors (Twenge \& Campbell, 2009 as cited in Boswell, 2012). Moreover, academically entitled students cannot differentiate appropriate behavior from inappropriate ones, and find inappropriate behaviors as more appropriate (Chowning \& Campbell, 2009). Similarly, students attributed positive or neutral meanings to academic entitlement, so they did not perceive academic entitlement negatively (Pimentel, 2011). Thus, they did not conform to social norms of academics and university policies (Kopp \& Finney, 2013). They frequently have conflicts and disputes with faculties unless faculties bend the rules for them personally, or make an exception for them. In short, they try to exploit 
AJESI - Anadolu Journal of Educational Sciences International, 2019; 9(2): 314-351

DOI: 10.18039/ajesi.577234

professors, institutional policies, etc. to attain their designated outcome. Stated in another way, they prefer more indirect and manipulative strategies to achieve the success instead of fulfilling their academic responsibilities. Consequently, they become socially maladjusted, their interpersonal relationships deteriorate and their tendency to academically dishonest behaviors increase due to academic entitlement (Menon \& Sharland, 2011). Therefore, the need for the investigation of academic entitlement construct in detail has become apparent (Pimentel, 2011). In the literature, since it was alleged that it is very similar to several psychological constructs like psychological entitlement, the first issue to be addressed has been the specification of academic entitlement as a distinct construct (Chowning \& Campbell, 2009; Jackson, Singleton-Jackson, \& Frey, 2011).

Inferred from the discussion so far, academic entitlement is related with various psychological constructs, and even it can be stated that it overlaps with some variables such as psychological entitlement, exploitive entitlement, and narcissism (Chowning \& Campbell, 2009). To clarify whether academic entitlement is distinct from these three constructs or not, the relationship of academic entitlement with these variables was investigated. Academic entitlement was found to be strongly related to psychological entitlement and narcissism (Greenberger, Lessard, Chuanshen, \& Farruggia, 2008). As individuals' psychological entitlement and narcissism increase, their academic entitlement also increases (Menon \& Sharland, 2011; Reinhardt, 2012). Psychological entitlement and narcissism were also found to explain significant variance in academic entitlement. In addition, academic entitlement was also found to be related to exploitive attitudes (Menon \& Sharland, 2011), and exploitive entitlement was the strongest predictor of academic entitlement (Greenberger et al., 2008).

Although these three variables were related to academic entitlement, academic entitlement has some components that differentiate from these constructs, and the relations are moderate. Thus, it can be stated that academic entitlement is a different construct from 
AJESI - Anadolu Journal of Educational Sciences International, 2019; 9(2): 314-351

DOI: 10.18039/ajesi.577234

psychological entitlement, exploitive entitlement and narcissism (Boswell, 2012; Chowning, \& Campbell, 2009; Greenberger et al., 2008; Kopp et al., 2011; Reinhardt, 2012). In other words, academically entitled students do not need to have an overall sense of entitlement, or their entitlement attitudes and behaviors are limited to only academic context (Campbell, Bonacci, Shelton, Exline, \& Bushman, 2004; Kopp et al., 2011). For this reason, at first, scale development studies were carried out to verify that academic entitlement is a different construct. In this process, different scales were developed. Some of these scales attempted to identify and measure academic entitlement in terms of the attitude dimension while others attempted to do this in terms of the behavior dimension (Reinhardt, 2012).

First of all, Achacoso (2002) carried out Exploratory Factor Analysis (EFA) and Confirmatory Factor Analysis (CFA) and obtained a-12 item two-dimensional scale, Entitlement Beliefs and Entitlement Actions. The correlation between Entitlement Beliefs and Entitlement Actions factors was found as 0.34 . Fit indices of a 12 -item scale was moderate and the construct of Academic Entitlement had adequate fit values, so the construct was confirmed. For external sources of validity studies, the relationship of academic entitlement with certain variables was examined. Both academic entitlement beliefs and actions were found to be correlated with general entitlement beliefs. Furthermore, academic entitlement beliefs and actions were found to be positively correlated with external attributions, but inversely related with internal attributions. Since academically entitled students attribute the outcomes they get to the external factors such as luck and context -professors, policy, etc. (Achacoso, 2002), they relinquish responsibility to the factors outside themselves especially when they fail (Chowning \& Campbell, 2009). Stated in another way, they attribute their academic failures to external factors to cope with low grades (Achacoso, 2002). That is, they think that their professors or university policies are responsible for their outcomes, so they have entitled expectations from professors about academic success. 
AJESI - Anadolu Journal of Educational Sciences International, 2019; 9(2): 314-351 DOI: 10.18039/ajesi.577234

Greenberger et al. (2008) also developed an instrument to measure academic entitlement in the study investigating the relationship between self-entitlement of college students and their personality, parents' generational status, educational attainment, and motivational factors. In an effort to develop a scale measuring this construct, they obtained a 15-item and unidimensional Academic Entitlement Scale. Cronbach alpha values were found as 0.87 in the first study and 0.86 in the second one. Moreover, correlations between academic entitlement and variables of psychological entitlement, exploitive entitlement and self-esteem were examined, and positive relationships were obtained with psychological entitlement and exploitive entitlement. Self-esteem was found to be negatively related to academic entitlement (Greenberger et al., 2008). Although they developed a scale, they didn't define and validate the construct of academic entitlement (Kopp \& Finney, 2013).

Trying to explain uncivil student behaviors, Chowning and Campbell (2009) offered a new construct that shed light on a matter. Since the construct of academic entitlement includes not only personal factors like entitlement but also situational factors about academic domain, they thought that the more variance in inappropriate behaviors could be explained by academic entitlement. Thus, their definition of academic entitlement incorporates both entitlement expectations and contextual factors that are beyond their control. They defined academic entitlement as an expectation of academic success abdicating the personal responsibility for achievement. Then they developed a scale with sub-dimensions of Externalized Responsibility and Entitled Expectations, and then confirmed a- two-factor structure with 15 items. These dimensions were found to be related, and the first one is about the students' and professors' responsibilities in an academic domain. The entitled expectations dimension is about the students' various academic expectations from professors. Since these sub-scales represent distinct constructs, total score from the whole scale cannot be obtained by simply adding the sum of each sub-scale's total score. Thus, all psychometric 
AJESI - Anadolu Journal of Educational Sciences International, 2019; 9(2): 314-351

DOI: 10.18039/ajesi.577234

characteristics were investigated in terms of sub-dimensions separately. Firstly, both dimensions were found to be positively correlated with general psychological entitlement. The externalized responsibility dimension explaining $24.38 \%$ of the variance was found to be positively related to the Entitlement/Exploitiveness subscale of the Narcissistic Personality Inventory (NPI), and grandiosity. On the other hand, a negative significant relationship was found between the externalized responsibility and personal control. Self-esteem was also found to be negatively related to the externalized responsibility. Therefore, it can be stated that individuals with low self-esteem exhibit academically entitled behaviors to preserve their self-esteem levels. The second factor of Entitled Expectations explaining $14.82 \%$ of the variance was found to be positively correlated with psychological entitlement. These results indicated that both factors (Externalized Responsibility and Entitled Expectations) are different from the similar constructs mentioned above despite they're related. Item-total correlations and Cronbach alpha coefficients indicated that these two factors are reliable constructs. At the same time, these two constructs were confirmed by means of further analysis. For predictive validity, the students' ability to differentiate appropriate behaviors from inappropriate ones was also investigated based on their academic entitlement levels and it was found that the lower the academic entitlement levels were, the higher the ability of distinguishing between appropriate and inappropriate behaviors was. In other words, academically entitled individuals have difficulty in assessing the appropriateness of a behavior. At the same time, both the externalized responsibility and the entitled expectations were found to be positively related to evaluation of inappropriate behavior as appropriate. That is, it was predicted that academically entitled students tend to exhibit more inappropriate behaviors (Chowning \& Campbell, 2009).

Jackson, Singleton-Jackson and Frey (2011) used various academic entitlement instruments and investigated the factor structure of them. Firstly, they tested whether a 15- 
AJESI - Anadolu Journal of Educational Sciences International, 2019; 9(2): 314-351

DOI: 10.18039/ajesi.577234

item Greenberger et al. (2008)'s scale is unidimensional or includes more than one dimension.

They found the two-factor structure that is parallel with the literature of academic entitlement.

Moreover, they carried out the factor analysis by adding extra 11 pilot items from SingletonJackson, Jackson and Reinhardt (2010)'s qualitative study about academic entitlement. They obtained a four-factor structure including previous two factors of responsibility and entitlement. The additional factors were called as control and product value of education. All these four factors were stated as the components of academic entitlement definition. At the same time, academic entitlement was found to be significantly related to learning styles, emotional intelligence and academic entitlement behaviors of participants.

Kopp et al. (2011) reviewed the academic entitlement scales or instruments in terms of psychometric properties. They evaluated certain academic entitlement scales according to Benson's (1998) program of construct validity. As a reference point, substantive stage of this program requires the construct to be predefined both theoretically and empirically. At structural stage, it is examined if an item was related to all the other items and the total score. At the third and the last stage, an external aspect of this accepted reference point was investigated by means of the relationship between the construct under investigation and other constructs (Kopp et al., 2011). Following Benson's (1998) program, Achacoso (2002)'s Academic Entitlement Scale development process was given credit for comprehensive literature review, but it was criticized for not taking account Benson's (1998) all three stages. In addition, Greenberger et al. (2008)'s and Chowning and Campbell (2009)'s Academic Entitlement Scales were also scrutinized and Kopp et al. (2011) bring honor to the all three research teams. On the other hand, some additional studies were suggested for these researchers to make their instruments more robust.

As a result of this review, Kopp et al. (2011) developed a new scale called as Academic Entitlement Questionnaire by means of taking Benson's (1998) construct validity 
AJESI - Anadolu Journal of Educational Sciences International, 2019; 9(2): 314-351

DOI: 10.18039/ajesi.577234

criteria into account. In this study, the items of the scale were prepared in the framework of academic entitlement literature and the five dimensions were designated as Knowledge as a Right (KR), Others should Provide education (OP), Problems in Learning are due to the factors outside learner (PL), Students should Control class rules (SC) and students Deserve particular outcomes because of the payment of Tuition (DT). They began the analysis with 26 items. They set four confirmatory models to determine the factor structure of the construct. They tested the most parsimonious one-factor model, bifactor model, second order model, and a five-factor model. They compared these models and concluded that one factor unidimensional model is the most plausible one among all others. Therefore, they selected the items that have larger pattern coefficients and represent general factor rather than facet factors. At the same time, a final eight-item scale included at least one item from each five facets to strengthen the content validity. Since some modifications were carried out with the first sample, the same models were also tested with a second sample, and one factor model was found to fit the data well. $\mathrm{R}^{2}$ values changed between 0.22 and 0.60 . Internal consistency coefficients were as 0.81 and 0.84 for two samples respectively. In an external stage, academic entitlement questionnaire was found to be correlated with psychological entitlement and self-esteem. Based on all these results and values, it can be stated that an-eight item instrument is valid and reliable.

Luckett et al. (2017) updated Greenberger et al. (2008)'s Academic Entitlement Scale to determine the typology of business school students according to academic entitlement by interviewing with a group of eight undergraduate students. Thus, they started factor analysis with 16 items and resulted in nine items under the three factors as behavioral entitlement, service entitlement and grade entitlement. Though this scale was the last scale developed, it was developed for business school students who comprised a limited and specific sample. 
AJESI - Anadolu Journal of Educational Sciences International, 2019; 9(2): 314-351

DOI: 10.18039/ajesi.577234

Since academic entitlement might result in various psychological and educational problems, the need for having a sound grasp of academic entitlement construct has recently led researchers to validate the academic entitlement construct and develop instruments like those mentioned above. These studies and initiatives about academic entitlement have been appreciated, but much more studies are still required (Anderson, Halberstadt, \& Aitken, 2013; Jackson, Singleton-Jackson, \& Frey, 2011). This is also the case for the studies in Turkey, because academic entitlement has not been taken into account systematically in Turkey, yet. This phenomenon, observed in many regions around the world, is a significant problem in Turkey as well. The problem of academic entitlement is stated as professors' complaints about students' impudent demanding behaviors and attitudes (Anderson et al., 2013). In Turkey, academics' personal stories comprise mostly students' inconvenient and disturbing attitudes and behaviors in recent years. In informal conversations with their colleagues, professors complain that students claim they deserve to pass courses and demand grades higher than those given to them just because they make efforts despite they can't meet the success criteria by due to incomplete and inadequate homeworks. In other words, it can be inferred from the anecdotes of professors that academic entitlement is a serious problem at universities in Turkey too. Therefore, to take the lead in the subject matter of academic entitlement in Turkey, it was intended to adapt previously validated instrument to Turkish culture at first in this study. For this aim, the literature was reviewed and several instruments were evaluated and it was decided to work on Kopp et al. (2011)'s Academic Entitlement Questionnaire, because this scale was the recently developed instrument when the study was put into practice. Moreover, reliability and validity studies of the scale were reported in detail and these results indicated that the instrument has strong psychometric properties, so Kopp et al. (2011)'s Academic Entitlement Questionnaire was adapted to Turkish culture. At the same time, in order to implement the Benson's (1998) third criteria of external source of validity, 
AJESI - Anadolu Journal of Educational Sciences International, 2019; 9(2): 314-351

DOI: 10.18039/ajesi.577234

studies about concurrent validity were carried out. More specifically, academic entitlement's relation with the Narcissism scale and the Entitlement subscale of the Young Schema Questionnaire-short form was examined. A positive relation with both scales was expected. Furthermore, the relation between academic self-efficacy and academic entitlement was investigated, and a negative relation between these two variables was expected. In this context, following research questions were investigated.

- Is the academic entitlement scale reliable in Turkish culture?

- Is the academic entitlement scale valid in Turkish culture?

- Are the points obtained from the academic entitlement scale are significantly and positively related to narcissism scores?

- Are the points obtained from the academic entitlement scale are significantly and positively related to entitlement scores?

- Are the points obtained from the academic entitlement scale are significantly and negatively related to self-efficacy scores?

\section{Methodology}

In this part, information about participants, instruments, procedure and analysis were presented.

\section{Participants}

The data of the study was gathered from 502 voluntary students of a public university in 2013-2014 academic year. Firstly, the data was examined and it was seen that 10 participants didn't answer many items. Thus, the data of these participants wasn't included in the analysis. Normality and Multivariate Normality of data were checked together. Firstly, descriptive statistics of median, mode and mean, histograms with normal curve and at the 
AJESI - Anadolu Journal of Educational Sciences International, 2019; 9(2): 314-351

DOI: 10.18039/ajesi.577234

same time skewness and kurtosis values were reviewed for checking the normality of the items of the Academic Entitlement Questionnaire and the total score of the four scales. It was seen that the distributions of the Academic Entitlement Questionnaire, the Entitlement, the Narcissism and the Academic Self-efficacy Scales are approximately normal. Therefore, the distributions of the Academic Entitlement Questionnaire items were examined by means of Mahalanobis Distance for checking multivariate normality of the data. As a result, since the scale was composed of 8 items, the significance value for 7 degrees of freedom was accepted therefore, the data of 23 participants above Mahalanobis' significance level was identified as outlier and eliminated. Therefore, the study was carried out with the data of 469 participants. The study group included 351 (75\%) female and $118(25 \%)$ male students. 178 (38\%) participants were freshmen, 78 (17\%) participants were sophomore, 114 (24\%) participants were junior and 98 (20\%) participants were senior. However, one participant didn't state his grade level.

\section{Instruments}

For the construct validity of Academic Entitlement Questionnaire, concurrent validity was conducted, so Narcissistic Personality Inventory, Entitlement subscale of Young Schema Questionnaire-Short Form Version 3 (YSQ-SF3) and Academic Self-Efficacy scale were utilized. A positive significant relationship was expected with narcissism and entitlement, whereas a negative significant relationship with academic self-efficacy was predicted. In this scope, the information about these instruments was provided.

Academic Self-Efficacy. Academic self-efficacy levels of the participants were quantified by Jerusalem and Schwarzer (1981)' s Academic Self-Efficacy Scale which was adapted to Turkish culture by Y1lmaz, Gürçay and Ekici (2007). The scale was adapted with the medical faculty students and included 7 items under one dimension. The scale is a four- 
AJESI - Anadolu Journal of Educational Sciences International, 2019; 9(2): 314-351

DOI: 10.18039/ajesi.577234

point Likert-type scale so the scale scores range from 7 to 28 . Internal consistency coefficient of the scale was found as 0.87 . In the study carried out for concurrent validity, the correlation coefficient between self-esteem and academic self-efficacy was found as 0.37 whereas the correlation coefficient between fear of performance and academic self-efficacy was found as 0.49 (Jerusalem ve Schwarzer 1981 as cited in Y1lmaz et al., 2007). The adaptation study was conducted with 672 students attending the three public universities in Ankara. One item of the seven-item scale is reverse coded. The higher the scale scores are, the higher the academic self-efficacy levels are. As a result of factor analysis, it was found that the scale was onedimensional just like the original scale and the item factor loadings ranged from 0.83 to 0.50 . The items explained $45 \%$ of the total variance. The internal consistency coefficient of the scale was found as 0.79 . In concurrent validity study, the correlation coefficient with Rosenberg Self-Esteem Scale, adapted to Turkish culture by Çuhadaroğlu (1985), was found as 0.44 . These results revealed that the scale was a valid and reliable instrument for Turkish culture.

Narcissistic Personality Inventory-16 (NPI-16). In order to find out the participants' levels of narcissistic personality traits, a 16-item short form of Narcissistic Personality Inventory was used. When this scale was firstly developed, it was composed of 40 items (NPI-40) under which the participants were required to select one of narcissistic and nonnarcissistic statements. At the end of the factor analysis, 7 factors of authority, superiority, self-sufficiency, exploitativeness, exhibitionism, entitlement and vanity were found out (Raskin \& Terry, 1988). Ames, Rose and Anderson (2006) tested if this instrument with fewer items would be a valid and reliable measure when necessary. By means of 5 studies, they ascertained that the 16-item short form measured individuals' narcissistic characteristics in a reliable and valid way. Firstly, the items were selected from NPI-40 and the long and the short forms were compared. In this first study, the relations of the both forms with Big Five 
AJESI - Anadolu Journal of Educational Sciences International, 2019; 9(2): 314-351

DOI: 10.18039/ajesi.577234

Personality traits were addressed. The means and the standard deviations of the two versions were very close to each other. The correlation between NPI-16 and NPI-40 was found as 0.90 . The internal consistency coefficient of NPI-16 was 0.72 while the internal consistency coefficient of NPI-40 was 0.84 . The mean inter-item correlations were found almost the same. In terms of validity, the variance explained by the first factor for the 16 -item version was $15 \%$ and for the 40 -item version was $19.9 \%$. Moreover, were the correlations between these two measures and the big five personality dimensions, self-esteem and Just World Scale examined, similar correlation patterns and values were obtained. In consequence, it was stated that the 16 -item version is as valid and reliable as the 40 -item version. In the second study, convergent and discriminant validity of the 16 -item version were examined with different participants. As it was expected, NPI-16 was found to be positively correlated with selfesteem, extraversion, self-monitoring and openness to experience. No significant relationship with dispositionism was obtained. Following this study, test-retest reliability was examined with a five-week interval in the third study and the correlation was found as 0.85 . In the next two studies, predictive validity of NPI-16 was investigated and these two studies also provided additional evidence for the validity of NPI-16. As a result, it can be stated that a 16item version of NPI with six factors except for vanity dimension is as valid and reliable as NPI-40. For practicality, NPI-16 was also adapted to Turkish culture by Atay (2009). After this adaptation study, NPI-16 has been used by many researchers from various disciplines. Atay (2009) firstly carried out translation and back translation procedures. Following this, they gathered pilot data and found Cronbach alpha as 0.57 that is below the acceptable level. Therefore, item-total correlation was examined and the items not making any significant contribution to the instrument were revised and restated. Then the data was gathered again and Cronbach alpha was obtained as 0.63 . For validity, explanatory factor analysis with principal component analysis was conducted and it was seen that the six factors as in the 
AJESI - Anadolu Journal of Educational Sciences International, 2019; 9(2): 314-351

DOI: 10.18039/ajesi.577234

original form explained the $60.8 \%$ of the total variance. Consequently, a valid and reliable instrument for measuring narcissistic characteristics was obtained. Some researchers such as Akıncı (2015) and Koşan (2015) using the instrument in their own studies reported Cronbach alpha values of NPI-16 as 0.69 and 0.66 respectively. Thus, additional evidence has been provided for validity and reliability of the 16-item version of NPI.

Young Schema Questionnaire-Short Form 3. In order to determine the entitlement levels of the participants, the entitlement/insufficient control sub-dimension of the Young Schema Questionnaire was used. Young developed a schema classification system to explain psychopathology and then developed a valid and reliable instrument called as The Young Schema Questionnaire that could be practically used in clinical environments (Young, 1990 as cited in Oei \& Baranoff, 2007).

Based on his clinical experiences, Young proposed 16 schemas as Abandonment, Defectiveness/Shame, Dependence/Incompetence, Emotional Deprivation, Emotional Inhibition, Enmeshment, Entitlement, Failure to Achieve, In-sufficient Self-Control, Mistrust/Abuse, Social Undesirability, Subjugation, Self-Sacrifice, Social Isolation/Alienation, Unrelenting Standards, and Vulnerability to Harm/Illness. Initially, Young (1994 as cited in Oei \& Baranoff, 2007) represented these 16 schemas with 205 items, and after factor analysis he revised the scale and got a construct with 18 schemas. These schemas are still kept on the scale (YSQ-LF) (Young, 2003 as cited in Soygüt, Karaosmanoğlu, \& Çakır, 2009). Schmidt, Joiner, Young and Telch (1995) carried out the first factor analysis and got a similar factor structure like Young's (1990, 1994 as cited in Oei \& Baranoff, 2007) except for the social desirability schema. Following this study, they repeated the factor analysis with the second sample consisting of different participants from the first study for cross validation. Except for Failure to Achieve, Entitlement, Subjugation and Social Undesirability schemas, the remaining 13 schemas obtained in the first study were 
AJESI - Anadolu Journal of Educational Sciences International, 2019; 9(2): 314-351

DOI: 10.18039/ajesi.577234

also attained with the second sample. The Entitlement items that would be used in this study were found to be loaded on the Insufficient Self-Control dimension.

Since the long form of YSQ takes long time to complete, Young (1998 as cited in Oei \& Baranoff, 2007) shortened this 205-item scale and reduced the number of items to 75 by using Schmidt et al. (1995)'s construct with fifteen schemas. Five items for each factor were selected on the basis of factor loading criteria. The first published factor analysis of the Young Schema Questionnaire-Short Form (YSQ-SF) was conducted by Welburn, Coristine, Dagg, Pontefract, \& Jordan (2002). As a result of this factor analysis, a reliable and valid construct was obtained parallel to previous versions. CFA was carried out with the Spanish version of the scale and the construct with fifteen schemas was confirmed. Baranoff, Oei, Kwon, and Cho (2006) conducted exploratory and confirmatory factor analysis with South Korean students and obtained 13 factors in these studies. Waller, Meyer and Ohanian (2001) found that each subscale had a Cronbach alpha higher than 0.80. Similarly, Stopa, Thorne, Waters, and Preston (2001) obtained and reported alpha scores for each sub-scale. Alpha values of the most of the subscales were found above 0.80 , while only four remaining subscales had internal consistency coefficients greater than 0.70 . The Dependence subscale was found to have an alpha level not greater than 0.70 . Cronbach's alpha values reported by Baranoff et al. (2006) were quite high (0.94). In conclusion, it can be stated that both YSQ-LF and YSQ-SF have similar psychometric values across diverse populations.

YSQ-SF was adapted to Turkish culture by Soygüt, Karaosmanoğlu and Çakır (2009). At the end of factor analysis, 15 factors were obtained, but it was indicated that 14 factors were more interpretable and meaningful. The higher order factor analysis yielded the result that 14 factors were grouped under five general factors. These higher order constructs were Impaired Autonomy, Disconnection, Unrelenting Standards, Other-Directedness, and Impaired Limits. For convergence validity, relationships between these sub-dimensions and 
AJESI - Anadolu Journal of Educational Sciences International, 2019; 9(2): 314-351

DOI: 10.18039/ajesi.577234

psychological symptoms were investigated. All schemas were found to be significantly related to General Symptom Inventory Index, Anxiety, Depression, Interpersonal sensitivity of SCL-90 as expected. The divergent validity analysis indicated that there was a significant difference between clinical and nonclinical samples in terms of the most of the schemas although no difference was found in terms of some schemas. The test-retest analysis carried out with a three-week interval showed that the correlation coefficients for the schema subdimensions ranged from 0.66 to 0.82 .

Cronbach alpha values of these 14 sub-dimensions changed between 0.63 and 0.80 , and a-seven-item subscale of the Entitlement/ Insufficient Self-Control under the "Impaired Limits" dimension was used in this study. The Entitlement/ Insufficient Self-Control schema was found to have an internal consistency of 0.72 and the test-re-test correlation was found as 0.66. As a result of all these analyses, it can be stated that Turkish version of YSQ-SF3 was reliable and valid in Soygüt et al.'s study (2009). Although the schemas overlapped with original schemas, some schemas were loaded on one construct. For instance, the entitlement and the insufficient self-control were combined into one construct, and this construct was used for concurrent validity in this study. The Entitlement/insufficient self-control contains seven items with a six point Likert scale, and the total score of the entitlement/insufficient self-control schema changes between 7 and 42. Therefore, as the points obtained from this subscale increase, the entitlement levels of the respondents also increase.

\section{Procedure}

Before beginning the adaptation study, Kopp was contacted by e-mail and his permission for adaptation of the scale was granted. After receiving the permission for adaptation, two researchers specialized on scale development and counselling, separately translated the items into Turkish. Then, translations were synthesized and items were 
AJESI - Anadolu Journal of Educational Sciences International, 2019; 9(2): 314-351

DOI: 10.18039/ajesi.577234

evaluated and in terms of comprehensibility and cultural relevance and congruity as well as equivalence between two forms by two researchers, and the final form was obtained. In the next stage, a faculty who has a good command of the both languages and come to Turkey after completing graduate education in America, compared Turkish and English versions of the form and made some suggestions. These suggestions were evaluated together with two researchers and the final version of the scale was obtained following a consensus of three experts. After the final Turkish form was obtained, by means of a pilot study, a small group of university students were asked to evaluate the instrument in terms of different aspects such as appearance and meaning. The participants stated that they understood the items and could easily answer. Thus, the final version of the Turkish form of the scale was obtained and the main study phase began. The research data was collected by the researcher. After the explanations were given to the potential participants, the data was collected from those who are voluntary. The participants weren't asked any identifying personal information and were told that they could withdraw from the research at any time they wished, the data would be kept confidential and be protected by the researcher.

In data analysis, to examine the structural validity of the scale, confirmatory factor analysis and concurrent validity were employed. In order to assess the reliability of the scale, test-retest reliability as well as internal consistency coefficient method was utilized. For language equivalence, the volunteer participants who are students of the English Language Teaching undergraduate programme and have a good command of the both languages and effectively use the both languages were applied Turkish and English with a three-week interval. The participants firstly answered the Turkish version of the form, and three weeks later they answered the English version. Since the participants weren't asked any identifying information, they were asked to identify a unique pseudonym for themselves and write it in the Turkish form at first step. Three weeks later, these participants answered the English form 
AJESI - Anadolu Journal of Educational Sciences International, 2019; 9(2): 314-351

DOI: 10.18039/ajesi.577234

by using their pseudonyms. After translational equivalence was provided, whether the scale was confirmed or not was tested through the Lisrel program. Furthermore, concurrent validity, Cronbach alpha coefficient and test-retest reliability techniques were utilized. Lisrel and SPSS programs were used in the analyses.

\section{Results}

This section includes findings about language equivalence, validity and reliability studies respectively. After the study of language equivalence, for reliability of the scale, internal consistency reliability and test-retest methods were utilized. Then confirmatory factor analysis was carried out for construct validity of Academic Entitlement Questionnaire. Moreover, concurrent validity was also conducted with additional 223 participants.

\section{Language Equivalence}

During the process in which the Academic Entitlement scale was adapted to Turkish culture, 30 students filled the Turkish form previously and three weeks later they answered the English form in the study carried out to examine language equivalence. The correlation between the Turkish and English forms of the scale was found as $0.73(\mathrm{p}<.01)$. It was reached that the difference between the means of the two forms (0.57) wasn't significant. As a result of the paired sample $t$-test, $t$ value was found as $-0.75(\mathrm{p}=0.46>.01)$. These results revealed that the Turkish form was equivalent to the original form.

\section{Reliability Analyses}

For reliability analysis, Cronbach alpha coefficient and test-retest analyses were carried out. The Cronbach alpha coefficient of the five-item scale was found as 0.66 . As a 
AJESI - Anadolu Journal of Educational Sciences International, 2019; 9(2): 314-351

DOI: 10.18039/ajesi.577234

result of the test-retest analysis conducted with 50 persons with a three-week interval, the correlation coefficient between the two assessments was found as $0.84(p<0.01)$. The paired sample $t$ test was used to investigate if the difference between the two assessments $(0.14)$ was significant, and the $t$ value of -0.29 wasn't found significant $(p=0.77>.01)$. These findings pointed out that the scale produced reliable results.

\section{Confirmatory Factor Analysis}

Confirmatory Factor Analysis was utilized to determine the structural validity of Turkish version of Academic Entitlement Questionnaire. The confirmatory factor analysis is used not only for testing the measurement model but also for adaptation studies. Hence, the confirmatory factor analysis of the unidimensional 8-item Academic Entitlement scale was conducted to investigate if the unidimensional structure worked in Turkish culture or not. During this process, covariance matrix and maximum likelihood were utilized. In the confirmatory factor analysis, firstly it is evaluated whether $t$ values of the item factor loadings are significant, and then it is investigated whether the data fitted latent construct according to fit values (Şimşek, 2007).

In this context, factor loading of the scale items were found significant. The chi-square value $\left(\chi^{2}(20, \mathrm{~N}=469)=116.46, \mathrm{p}<0.001\right)$ was found significant, but it is sensitive to sample size and large sample sizes are expected to result in significant results. Therefore, division of the chi-square value by the degrees of freedom is suggested and the value less than five indicates good fit (Sümer, 2000). In the study, $\chi^{2} / \mathrm{df}$ value is 5.82 . Evaluation of the goodnessof-fit indexes $(\mathrm{RMSEA}=0.10, \mathrm{SRMR}=0.07, \mathrm{GFI}=0.94, \mathrm{AGFI}=0.89, \mathrm{CFI}=0.87, \mathrm{NNFI}=0.82)$ showed that the data did not fit to the model. In this framework, the correlations between the items of the scale were examined and it was determined that the error variances of the items number two, three and seven were quite high $(0.95,0.89$ and 0.90 respectively), and thus the 
AJESI - Anadolu Journal of Educational Sciences International, 2019; 9(2): 314-351 DOI: 10.18039/ajesi.577234

variances they explained were quite low $(0.22,0.32$ and 0.32 respectively). Therefore, the items number two, three and seven were deleted from the model and then the analysis was repeated. Following this analysis, it was ascertained that the all path coefficients from the latent variable to the observed variables (items) were significant and the $t$ values ranged from 7.34 to 14.38 . The chi-square value $\left(\chi^{2}(5, \mathrm{~N}=469)=9.63, \mathrm{p}<0.09\right)$ was not significant. In other words, it was concluded that the data fit to the model due to the fact that the difference between the data and the model wasn't statistically significant. Furthermore, the value obtained through division of the chi-square value by the degrees of freedom $\left(\chi^{2} / \mathrm{df}=1.93\right)$ reflected a perfect fit.

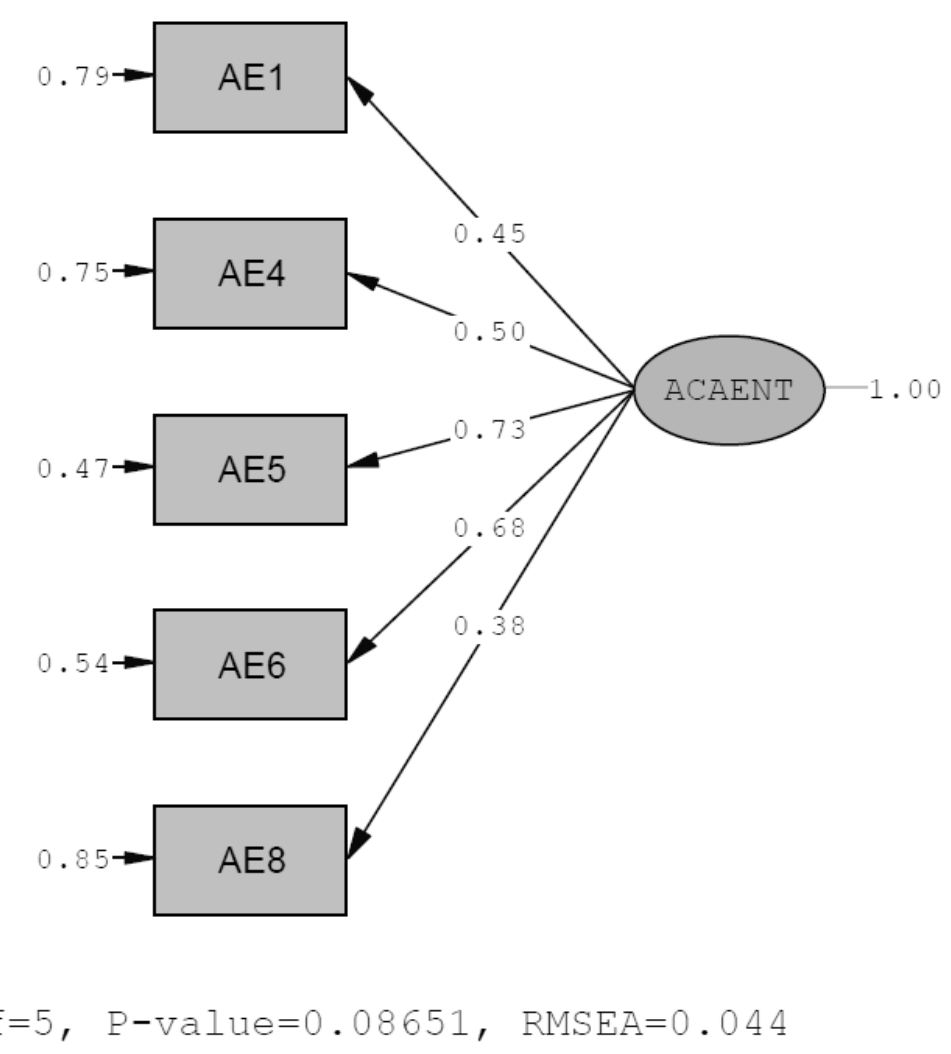

Figure 1. The standardized regression coefficients of scale items

As the goodness-of-fit indexes $(\mathrm{RMSEA}=0.04, \mathrm{SRMR}=0.03, \mathrm{GFI}=0.99, \mathrm{AGFI}=0.98$, $\mathrm{CFI}=0.99, \mathrm{NNFI}=0.98$ ) were examined, the data was found to fit the model perfectly. In this 
AJESI - Anadolu Journal of Educational Sciences International, 2019; 9(2): 314-351

DOI: 10.18039/ajesi.577234

way, the unidimensional five-item scale was confirmed. The standardized regression coefficients of each item are shown in Figure 1 and they range from 0.38 to 0.73 . The explained variance values were determined as $0.21,0.25,0.53,0.46$ and 0.15 respectively.

\section{Concurrent Validity}

For concurrent validity, the relationships between academic entitlement and narcissistic personality, entitlement, and academic self-efficacy were examined with additional 223 participants. The academic entitlement was found to be positively related with Narcissistic Personality $(0.16, \mathrm{p}<0.05)$ and Entitlement dimension of Early Maladaptive Schemas (0.26) as expected at 0.01 significance level. A negative significant relationship (0.15) was obtained between academic self-efficacy and academic entitlement $(p<0.05)$. As narcissistic and entitlement tendencies rise, academic entitlement levels also increase. On the other hand, the higher the academic self-efficacy is, the lower the entitlement levels are. Because higher level of academic self-efficacy leads to the belief that individuals can control and change what happen to them, it gives rise to the decrease in academic entitlement (Reinhardt, 2012). All these results indicated that academic entitlement is a different but related construct with narcissism, entitlement and academic self-efficacy.

\section{Discussion and Conclusion}

Kopp et al. (2011) reviewed the psychometric properties of the academic entitlement instruments according to Benson's (1998) criteria. They evaluated Achacoso (2002)'s, Greenberger et al. (2008)'s, Chowning and Campbell (2009)'s, and Jackson et al. (2011)'s Academic Entitlement Scales. They concluded that although these researchers met some of Benson's (1998) criteria, they could not fulfill all the criteria. Thus, Kopp et al. (2011) 
AJESI - Anadolu Journal of Educational Sciences International, 2019; 9(2): 314-351

DOI: 10.18039/ajesi.577234

developed a scale of Academic Entitlement Questionnaire by taking account all of Benson's criteria. Like Jackson et al. (2011), Kopp et al. (2011) wrote items reflecting the dimensions of responsibility, unreasonable expectations, control and students as consumers. Kopp et al. (2011) tested four different models with various combinations and found that the most parsimonious one-factor model is the best one. Therefore, they selected the items with larger pattern coefficients from all dimensions and obtained a more representative and comprehensive scale. Due to parsimoniousness and comprehensiveness of the Kopp et al. (2011)'s instrument, it was decided to adapt this instrument to Turkish university students. As it was expected, Academic Entitlement Questionnaire was confirmed as one-dimensional construct. Although three items were omitted because of higher error covariances and lower explained variance, this scale still includes the items representing the three factors except for the consumer perception. As a result, a-five item one-dimensional Academic Entitlement Questionnaire was confirmed with Turkish university students. The standardized pattern coefficients were found between 0.38 and 0.73 in this study, and these values are similar to that of the original version of Academic Entitlement Questionnaire. It was seen in Kopp et al. (2011)'s study that the standardized pattern coefficients with the first sample changed between 0.53 and 0.73 , and with the second sample changed between 0.57 and 0.78 . This indicates that the items in Turkish version work almost in a similar manner as the items in the original version.

The finding about unidimensionality of the Turkish version is consistent with Kopp et al. (2011)'s and Greenberger et al. (2008)'s findings. Since the adapted scale is a construct with one factor, it includes items about students' and professors' responsibilities and students' unreasonable entitled expectations under one factor. Due to the inclusion of these items, the scale is also similar to Achacoso (2002)'s, Chowning and Campbell (2009)'s, and Jackson et al. (2011)'s multidimensional constructs in a way that the same content is just grouped under 
AJESI - Anadolu Journal of Educational Sciences International, 2019; 9(2): 314-351

DOI: 10.18039/ajesi.577234

more than one factor in these instruments. Although these three instruments have more than one factor, it is seen that the factors consist of the items about responsibility, control and entitled expectations (Jackson et al., 2011). Therefore, it can be stated that the adapted instrument is also similar to Achacoso (2002)'s and Chowning and Campbell (2009)'s, and Jackson et al. (2011)'s scales in terms of content.

In a third, an external stage of Benson's (1998) program, the relationship of academic entitlement with several variables was investigated to indicate whether academic entitlement is a related but different construct. Academic entitlement was found to be significantly and positively related with entitlement. This finding is consistent with the literature (Achacoso, 2002; Chowning and Campbell, 2009; Greenberger et al., 2008; Kopp et al., 2011). In this study, the relationship was found significant but it was not strong. This indicates that despite the fact that academic entitlement is related with entitlement, it is a different construct. Moreover, the relationship between academic entitlement and narcissism was also investigated for external source of validity. A significant but weak relationship between academic entitlement and narcissism was obtained, so it can be stated that this is an evidence for an external source of validity just like the case in Chowning and Campbell (2009)'s study. This means that academic entitlement is a context dependent construct. In other words, academically entitled individuals do not need to be generally entitled and have global narcissistic tendencies (Reinhardt, 2012).

Since academically entitled students do not take responsibility of their academic performances, they are more likely to attribute their failures to external factors (Achacoso, 2002) and make less effort (Kopp et al., 2011). For this reason, it was inferred that academic entitlement was negatively correlated with self-efficacy and it was taken as another external source of construct validity like Boswell (2012) did. In the study, a negative significant relationship between these two constructs was obtained as expected. This finding is parallel to 
AJESI - Anadolu Journal of Educational Sciences International, 2019; 9(2): 314-351

DOI: 10.18039/ajesi.577234

the findings of Boswell (2012). Moreover, this is similar to Chowning and Campbell (2009) and Greenberger et al. (2008)'s studies indicating that self-esteem was negatively related with academic entitlement. Self-esteem is a general sense of self-worth resulting from selfevaluation and it is highly correlated with self-efficacy. Even it can be stated that self-efficacy results in higher self-esteem because self-efficacy is an expectation of making effect on something and leads individuals to think that they can change consequences and achieve their goals. Thus, individuals with higher self-efficacy are more likely to take an action and make an attempt to acquire desired goals. Probably they get the desired outcome, and they evaluate themselves positively and have more positive attitudes toward themselves, and eventually boost their self-esteem. In contrast, academically entitled students are more likely to have external locus of control, and think that they cannot get the expected outcome and they expect others do something for them (Kopp et al., 2011) so their self-efficacy levels decrease. That is, they relinquish their responsibilities. The same applies for academic situations. For this reason, acquisition of an inverse relationship between academic self-efficacy and academic entitlement is more probable (Gardner \& Pierce, 1998). As a result, it can be stated that academic entitlement is a distinct and valid construct according to all these findings. These findings about external source of validity are parallel to Reinhardt (2012)'s findings about the distinctiveness and the validity of academic entitlement construct.

In addition to validity studies, the reliability of the instrument was investigated and Cronbach alpha coefficient was found as 0.66 that is in a range of acceptable limits (Hinton, Brownlow, McMurray, \& Cozens, 2004) although it is a little bit low. This lower level may be because of the lower number of items. Thus, internal reliability can be investigated with different samples in later studies to see if this relatively low level is caused by the lower number of items. In addition, test-retest analysis was carried out with a-three-week interval and a significant and strong relationship was obtained, and no significant difference between 
AJESI - Anadolu Journal of Educational Sciences International, 2019; 9(2): 314-351

DOI: 10.18039/ajesi.577234

these two estimates was found. This result indicates that Academic Entitlement Questionnaire produce consistent results across time.

As a consequence, a seven-point Likert type Academic Entitlement Questionnaire was confirmed as a one factor construct with five items. The Academic Entitlement Questionnaire was found to be related with entitlement, narcissism and academic self-efficacy. That is, the research findings revealed that the Academic Entitlement Questionnaire is a valid and reliable instrument which can be used to determine the academic entitlement levels of the university students in Turkey.

Academic entitlement is one of the significant problems of the current education system in Turkey like all over the world and negatively affects education quality, individuals' psychological well-being and their relationships with others. Academic entitlement, particularly displayed in the form of not taking responsibility, making insufficient effort, trying to control others (professors, friends) instead of changing and correcting his/her own behaviors and demanding service as a customer rather than a student, is considered to cause important problems in the future. Hence, it is crucial to determine the academic entitlement levels of students, raise the awareness of the society (family and school personnel) about academic entitlement and carry out studies on preventing academic entitlement. Replacing individuals' unreasonable expectations with realistic forms and supporting them to take the responsibility of themselves and their behaviors through increasing their self-efficacy levels will increase their psychological and social adaptation and also enable them to benefit from education at the highest degree.

The study on adaptation of Academic Entitlement Questionnaire to Turkish university students results in a valid and reliable instrument, but it should be improved with further studies. For language equivalence assessment between the original scale and its Turkish version, firstly the Turkish version and then the English version was applied in this study. To 
AJESI - Anadolu Journal of Educational Sciences International, 2019; 9(2): 314-351

DOI: 10.18039/ajesi.577234

eliminate the primacy and recency effect, the data can be gathered simultaneously from another group completing the English version firstly and the Turkish version three weeks later. For validity, predictive validity can also be implemented. Psychometric characteristics may be examined across various participants. For concurrent validity, different instruments for the related constructs can be used together with the Academic Entitlement Questionnaire.

\section{References}

Achacoso, M. V. (2002). “What do you mean my grade is not an A?" An investigation of academic entitlement, causal attributions, and self-regulation in college students. (Unpublished doctoral dissertation). Available from ProQuest Dissertations and Theses Global Database. (UMI No. 3225897)

Akınc1, İ. (2015). The relationship between the types of narcissism and psychological wellbeing: The roles of emotions and difficulties in emotion regulation. [Narsisizm türleri ve psikolojik iyilik hali arasındaki ilişki: Duyguların ve duygu düzenleme güçlüklerinin rolü.] (Master Thesis. Orta Doğu Teknik Üniversitesi, Ankara, Türkiye). Retrieved from http://etd.lib.metu.edu.tr/upload/12619052/index.pdf

Ames, D. R., Rose, P., \& Anderson, C. P. (2006). The NPI-16 as a short measure of narcissism. Journal of Research in Personality, 40(4), 440-450. https://doi.org/10.1016/j.jrp.2005.03.002

Anderson, D., Halberstadt, J., \& Aitken, R. (2013). Entitlement attitudes predict students' poor performance in challenging academic conditions. International Journal of Higher Education, 2(2), 151-158. doi:10.5430/ijhe.v2n2p151

Atay, S. (2009). Narsistik Kişilik Envanteri'nin Türkçe’ye standardizasyonu. Gazi Üniversitesi İktisadi ve İdari Bilimler Fakültesi Dergisi, 11(1), 181-196. Retrieved from 
AJESI - Anadolu Journal of Educational Sciences International, 2019; 9(2): 314-351

DOI: 10.18039/ajesi.577234

https://scholar.google.com.tr/scholar?output=instlink\&q=info:aS2DGracyxoJ:scholar.go

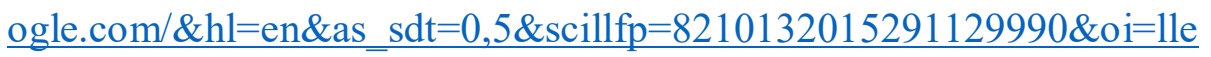

Baranoff, J., Oei, T. P., Cho, S. H., \& Kwon, S. M. (2006). Factor structure and internal consistency of the Young Schema Questionnaire (Short Form) in Korean and Australian samples. Journal of Affective Disorders, 93(1-3), 133-140. doi:10.1016/j.jad.2006.03.003

Barton, A. L., \& Hirsch, J. K. (2016). Permissive parenting and mental health in college students: Mediating effects of academic entitlement. Journal of American College Health, 64(1), 1-8. doi: 10.1080/07448481.2015.1060597

Benson, J. (1998). Developing a strong program of construct validation: A test anxiety example. Educational Measurement: Issues and Practice, 17, 10-17.

Boswell, S. S. (2012). "I deserve success": Academic entitlement attitudes and their relationships with course self-efficacy, social networking, and demographic variables. Social Psychology of Education, 15(3), 353-365. doi:10.1007/s11218-012-9184-4

Campbell, W. K., Bonacci, A. M., Shelton, J., Exline, J. J., \& Bushman, B. J. (2004). Psychological entitlement: Interpersonal consequences and validation of a self-report measure. Journal of Personality Assessment, 83(1), 29-45. Retrieved from https://doi.org/10.1207/s15327752jpa8301pass:[_]04

Chowning, K. \& Campbell, N. J. (2009). Development and validation of a measure of academic entitlement: Individual differences in students' externalized responsibility and entitlement expectations. Journal of Educational Psychology, 101, 982-997. doi:10.1037/a0016351

Ciani, K. D., Summers, J. J., \& Easter, M. A. (2008). Gender differences in academic entitlement among college students. The Journal of Genetic Psychology, 169(4), 332344. Retrieved from https://doi.org/10.3200/GNTP.169.4.332-344 
AJESI - Anadolu Journal of Educational Sciences International, 2019; 9(2): 314-351

DOI: 10.18039/ajesi.577234

Çuhadaroğlu, F. (1985). Adolesanlarda benlik saygısı. (Yayımlanmamış yüksek lisans tezi). Hacettepe Üniversitesi, Ankara, Türkiye.

Gardner, D. G., \& Pierce, J. L. (1998). Self-esteem and self-efficacy within the organizational context: An empirical examination. Group \& Organization Management, 23, 48-70. doi: $10.1177 / 1059601198231004$

Gotschall, N. P. (2016). Teaching in the Entitlement Age: Faculty Perceptions Regarding Student Academic Entitlement Behavior. Retrieved from https://scholarworks.waldenu.edu/cgi/viewcontent.cgi?article $=2799 \&$ context $=$ dissertati $\underline{\text { ons }}$

Greenberger, E., Lessard, J., Chen, C., \& Farruggia, S. P. (2008). Self-entitled college students: Contributions of personality, parenting, and motivational factors. Journal of Youth and Adolescence, 37, 1193-1204. doi: 10.1007/s10964-008-9284-9

Hartman, T. B. (2012). An analysis of university student academic self-entitlement: Levels of entitlement, academic year, and gender. (Master Thesis). Available from ProQuest Dissertations and Theses Global Database. (UMI No. 1510403).

Hinton, P. R., Brownlow, C., McMurray, I., \& Cozens, B. (2004). SPSS explained. London: Routledge.

Hwang, Y. G. (1995). Student apathy, lack of self-responsibility and false self-esteem are failing American schools. Education, 115, 484-490.

Jackson, D. L., Singleton-Jackson, J. A., \& Frey, M. P. (2011). Report of a Measure of Academic Entitlement. American International Journal of Contemporary Research, 1(3), 53-65. Retrieved from

http://www.aijcrnet.com/journals/Vol_1_No_3_November_2011/8.pdf 
AJESI - Anadolu Journal of Educational Sciences International, 2019; 9(2): 314-351

DOI: 10.18039/ajesi.577234

Juvonen, J., Le, Vi-Nhuan, Kaganoff, T., Augustine, C. H., \&Constant, L. (2004). Focus on the wonder years: Challanges facing the American middle school. USA: RAND Corporation.

Kazdin, A. E. (1993). Adolescent mental health: Prevention and treatment programs. American Psychologist, 48, 127-141.

Kershaw, T. (1992). The effects of educational tracking on the social mobility of African Americans. Journal of Black Studies, 23(1), 152-169.

Kopp, J. P., \& Finney, S. J. (2013). Linking academic entitlement and student incivility using latent means modeling. The Journal of Experimental Education, 81(3), 322-336. doi:10.1080/00220973.2012.727887

Kopp, J. P., Zinn, T. E., Finney, S. J., \& Jurich, D. P. (2011). The development and evaluation of the academic entitlement questionnaire. Measurement and Evaluation in Counseling and Development, 44(2), 105-129. doi: 10.1177/0748175611400292

Koşan, Y. (2015). Üniversite öğrencilerinin facebook kullanımının narsisizm ve saldırganlık düzeyleri ile ilişkisinin incelenmesi. (Yayımlanmamış yüksek lisans tezi). Yüzüncü Yı1 Üniversitesi, Van, Türkiye.

Lippmann, S., Bulanda, R. E., \& Wagenaar, T. C. (2009). Student entitlement: Issues and strategies for confronting entitlement in the classroom and beyond. College Teaching, 57(4), 197-204. Retrieved from https://link.springer.com/content/pdf/10.1007/s11218-

\section{2-9184-4.pdf}

Lombardi, J. V. (2007). The Academic Success Entitlement. Inside Higher Education, 26. Retrieved from https://www.insidehighered.com/blogs/reality-check/academic-success$\underline{\text { entitlement }}$ 
AJESI - Anadolu Journal of Educational Sciences International, 2019; 9(2): 314-351

DOI: 10.18039/ajesi.577234

Luckett, M., Trocchia, P. J., Noel, M. N., \& Marlin, D. (2017). A typology of students based on academic entitlement. Journal of Education for Business, 92(2), 96-102. doi:10.1080/08832323.2017.1281214

Luckett, M., Trocchia, P. J., Noel, N. M., \& Marlin, D. (2017) A typology of students based on academic entitlement. Journal of Education for Business, 92(2), 96-102. doi:10.1080/08832323.2017.1281214

Menon, M. K., \& Sharland, A. (2011). Narcissism, exploitative attitudes, and academic dishonesty: An exploratory investigation of reality versus myth. Journal of Education for Business, 86, 50-55. doi: 10.1080/08832321003774772

Miller, B. K. (2013). Measurement of academic entitlement. Psychological Reports: Sociocultural Issues in Psychology, 113(2), 654-674. doi: 10.2466/17.08.PR0.113x25z1

Miller, M. A., \& Murray, C. (2005). Advising academically underprepared students. NACADA Clearinghouse of Academic Advising Resources. Retrieved from https://www.nacada.ksu.edu/Resources/Clearinghouse/View-Articles/Academically$\underline{\text { underprepared-students.aspx }}$

Morrow, W. (1994). Entitlement and achievement in education. Studies in Philosophy and Education, 13, 33-47. doi: https://doi.org/10.1007/BF01074084 Retrieved from https://link.springer.com/content/pdf/10.1007\%2FBF01074083.pdf

Oei, T. P. S. \& Baranoff, J. (2007). Young Schema Questionnaire: Review of Psychometric and measurement issues. Australian Journal of Psychology. 59 (2), 78-86. doi:10.1080/00049530601148397

Pimentel, M. (2011). Perceptions and realities of academic entitlement behaviors, beliefs, and actions within the basic skills student population at the two-year college. (Doctoral Dissertation). Available from ProQuest Dissertations and Theses Global Database. (UMI No.3457973). 
AJESI - Anadolu Journal of Educational Sciences International, 2019; 9(2): 314-351

DOI: 10.18039/ajesi.577234

Raskin, R., \& Terry, H. (1988). A principal-components analysis of the Narcissistic Personality Inventory and further evidence of its construct validity. Journal of Personality and Social Psychology, 54(5), 890-902. Retrieved from https://scholar.google.com.tr/

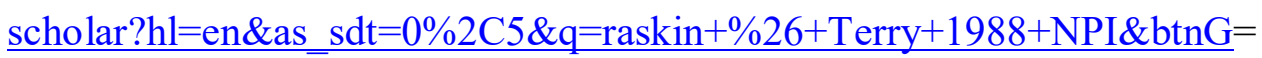

Reinhardt, (2012). Conceptualizing academic entitlement: What are we measuring?. (Master Thesis). Available from ProQuest Dissertations and Theses Global Database. (UMI No. MR77287).

Roeser, R. W., Eccles, J. S., \& Sameroff, A. J. (1998). Academic and emotional functioning in early adolescence: Longitudinal relations, patterns, and prediction by experience in middle school. Development and Psychopathology, 10(2), 321-352.

Schmidt, N. B., Joiner, T. E., Young, J. E., \& Telch, M. J. (1995). The Schema Questionnaire: Investigation of psychometric properties and the hierarchical structure of maladaptive schemas. Cognitive Therapy and Research, 19, 295 - 321. Retrieved from https://labs.la.utexas.edu/telch/files/2015/02/The-Schema-Questionnaire.pdf

Shapiro, D. P. (2012). Entitled to cheat: An examination of ıncoming freshmen at a small regional university. The Journal of Public and Professional Sociology, 4(1), 1-14.

Singleton-Jackson, J. A., Jackson, D. L., \& Reinhardt, J. (2010). Students as consumers of knowledge: Are they buying what we're selling? Innovative Higher Education, 35, $343-$ 358. https://doi.org/10.1007/s10755-010-9151-y

Singleton-Jackson, J. A., Jackson, D. L., \& Reinhardt, J. (2011). Academic entitlement: Exploring definitions and dimensions of entitled students. The International Journal of Interdisciplinary Social Sciences, 5, 229-236. Retrieved from http://search.ebscohost.com/login.aspx?direct=true \&db=a9h\&AN=73151254\&lang=tr\& $\underline{\text { site }=\text { eds-live \&authtype }=\text { uid }}$ 
AJESI - Anadolu Journal of Educational Sciences International, 2019; 9(2): 314-351

DOI: 10.18039/ajesi.577234

Soygüt, G., Karaosmanoğlu, A., \& Çakır, Z. (2009). Erken dönem uyumsuz şemaların değerlendirilmesi: Young şema ölçeği kısa form 3'ün psikometrik özelliklerine ilişkin bir inceleme. Türk Psikiyatri Dergisi, 20(1), 78-84. Retrieved from http://www.turkpsikiyatri.com/c20s1/75-84.pdf

Stopa, L., Thorne, P., Waters, A., \& Preston, J. (2001). Are the short and long forms of the Young Schema Questionnaire comparable and how well does each version predict psychopathology scores? Journal of Cognitive Psychotherapy: An International Quarterly, 15, 253-272. doi: 10.1891/0889-8391.15.3.253

Sümer, N. (2000). Yapısal eşitlik modelleri: Temel kavramlar ve örnek uygulamalar. Türk Psikoloji Yazılarl, 3(6), 49-74.

Şimşek, Ö. F. (2007). Yapısal eşitlik modellemesine giriş. Temel ilkeler ve LISREL uygulamalart. Ankara: Ekinoks Yayınevi.

Twenge, J. M. (2009). Generational changes and their impact in the classroom: Teaching Generation Me. Medical Education, 43(5), 398-405. Retrieved from https://onlinelibrary.wiley.com/doi/pdf/10.1111/j.1365-2923.2009.03310.x

Twenge, J. M., \& Campbell, W. K. (2008). Increases in positive self-views among high school students: Birth-cohort changes in anticipated performance, self-satisfaction, selfliking, and self-competence. Psychological Science, 19(11), 1082-1086. doi: $10.1111 /$ j.1467-9280.2008.02204.x

Waller, G., Meyer, C. \& Ohanian, V. (2001). Psychometric properties of the long and short versions of the Young Schema Questionnaire: Core beliefs among bulimic and comparison women. Cognitive Therapy and Research, 25(2), 137-147. doi: https://doi.org/10.1023/A:1026487018110 
AJESI - Anadolu Journal of Educational Sciences International, 2019; 9(2): 314-351 DOI: 10.18039/ajesi.577234

Welburn, K. R., Coristine, M., Dagg, P., Pontefract, A., \& Jordan, S. (2002). The Schema Questionnaire-Short Form: Factor analysis and relationship between schemas and symptoms. http://dx.doi.org/10.1023/A:1016231902020

Yılmaz, M., Gürçay, D., \& Ekici, G. (2007). Akademik özyeterlik ölçeğinin Türkçe’ye uyarlanmas1 (Adaptation of the academic self-efficacy scale to Turkish). Hacettepe Üniversitesi Eğitim Fakültesi Dergisi (H. U. Journal of Education), 33, 253-259. Retrieved from http://dergipark.gov.tr/download/article-file/87651 